\title{
Wyłączne prawo do odmiany (breeder's right) w obszarze własności intelektualnej
}

Pojęcie „własność intelektualna” zastąpiło w dużej mierze pojęcie „,dobra niematerialne", które jako samoistne przedmioty intelektualne stanowią punkt odniesienia wyłącznych i bezwzględnych praw podmiotowych i jako takie są przeciwstawiane wyodrębnionym przedmiotom materialnym, czyli rzeczom w rozumieniu art. $45 \mathrm{kc}^{1}$

Potrzeba takiego pojęcia zbiorczego „własność intelektualna” wprowadzona została do Konwencji o Światowej Organizacji Własności Intelektualnej (WIPO OMPI) z 1967 r. i związana jest z pojawianiem się coraz to nowej kategorii dóbr intelektualnych, które „rozsadzają” ramy dwu tradycyjnych obszarów zarezerwowanych dla tego rodzaju dóbr prawnych, tj. „,własności literackiej i artystycznej” oraz „własności przemysłowej”. ${ }^{2}$

Pojęcie własności intelektualnej w ustawodawstwie poszczególnych państw ulega ciągłemu poszerzaniu, również ze względu na przystępowanie do konwencji międzynarodowych, traktatów i porozumień. Przede wszystkim jednak zakres przedmiotowy nieustannie powiększa się, a to przez fakt, że coraz większa liczba tzw. przedmiotów intelektualnych zyskuje status dóbr niematerialnych, czyli dóbr, które stają się przedmiotem kreowanych przez ustawodawcę praw wyłącznych. Dotyczy to zarówno obszaru prawa własności literackiej i artystycznej, jak też prawa własności przemysłowej.

Poglądy doktryny na wzajemną relację nazw „własność intelektualna” i „,własność przemysłowa" nie zostały dotąd uzgodnione. Uznaje się, że własność intelektualna jest pojęciem szerszym pod względem logicznym, nadrzędnym w stosunku do własności przemysłowej (takie podejście przyjęto w Konwencji WIPO). Wedle innej opinii własność przemysłowa i własność intelektualna są odrębnymi, chociaż bardzo bliskimi sobie dziedzinami własności na dobrach niematerialnych,

A. Kopff, Prawo cywilne a prawo dóbr niematerialnych, ZN UJ PWOWI 1975, z. 5, s. 7 i n.

Tak M. Poźniak-Niedzielska, Ewolucja prawa własności intelektualnej w dobie współczesnej, Państwo i Prawo 2002, nr 10, s. 8. 
ze względu na odrębność podstawowych zasad ochrony patentowej i autorskoprawnej. ${ }^{3} \mathrm{~F}$. Zoll w $1931 \mathrm{r}$. napisał, iż ,własność przemysłowa nie jest pojęciem jednolitem i niem - zdaje się - nigdy nie będzie ${ }^{4}$."

Prawa do odmian roślin, uregulowane w ustawie z dnia 26 czerwca 2003 r. o ochronie prawnej odmian roślin ${ }^{5}$, zaliczane są do obszaru praw własności przemysłowej, jakkolwiek nie są wymienione w art. 2. Konwencji Paryskiej o ochronie własności przemysłowej z 1883 r., a zatem nie można twierdzić, że podlegają jej postanowieniom. Konwencja Paryska nie wymienia odmiany rośliny jako przedmiotu ochrony własności przemysłowej (art. 1 ust. 2). W doktrynie spotyka się wyraźne stwierdzenie, że odmiany roślin ,niewątpliwie powinny być zaliczane do własności przemysłowej"6. Nie jest jednak jasne, czy w Konwencji wymienione zostały wszystkie przedmioty ochrony, czy też tylko te, które podlegają ochronie patento$w^{{ }^{7}}$. Biorąc pod uwagę, że Konwencja zalicza do przedmiotu własności przemysłowej nasiona, można twierdzić, że własność przemysłowa w szerokim rozumieniu obejmuje również wyłączne prawo do odmiany rośliny. ${ }^{8}$ Mimo braku ustawowego określenia stosunku do przepisów Konwencji Paryskiej - należy przyjąć, że prawo wyłączne do odmiany rośliny można określić jako prawo sui generis. Odmiana rośliny nie mogła pojawić się w zrewidowanym tekście Konwencji Paryskiej (tekst sztokholmski z 1967 r. ) chociażby dlatego, że na początku lat 60-tych ustalono na forum międzynarodowym wyłączenie ochrony prawnej w tym zakresie w odrębną Konwencję międzynarodową o ochronie odmian roślin UPOV ${ }^{9}$, o której dalej.

Prawo wyłączne, zwane również prawem hodowcy należy zatem traktować jako prawo sąsiednie, czy nawet pokrewne prawom objętym zbiorową nazwą własności przemysłowej, pomimo że w tym wypadku brak jest wyraźnej legitymizacji tego pokrewieństwa, która występuje w prawie autorskim w odniesieniu do praw do fonogramów i videogramów, wykonań artystycznych, czyli praw pokrewnych prawu autorskiemu.

Tak. A.Szewc, G. Jyż, Prawo własności przemysłowej, Warszawa 2003, s. 2 i n. F. Zoll nazywał prawa na dobrach niematerialnych „prawami podobnymi do rzeczowych”, zob. F. Zoll, Prawo cywilne, tom II, Prawa rzeczowe i rzeczowym podobne, Poznań 1931, s. 114 i n.

$4 \quad$ F. Zoll, Prawo cywilne, tom II, Prawa rzeczowe i rzeczowym podobne, s. 143.

5 Dz.U. Nr 137, poz. 1300 ze zm.

6 Tak (w:) E. Nowińska, U. Promińska, M. du Vall, Prawo własności przemysłowej, Warszawa 2007, s. 16.

7 Zob. A. Szewc, M. Kępiński, (w:) A. Adamczak, A. Szewc (red.): Konwencja paryska o ochronie własności przemysłowej. Komentarz, Warszawa 2008, s. 60.

$8 \quad$ Konwencja paryska traktuje własność przemysłową bardzo szeroko, stosując to pojęcie nie tylko do przemysłu i handlu w ścisłym znaczeniu, ale również do przemysłów rolnych i wydobywczych oraz do wszelkich produktów wytworzonych lub naturalnych, $\mathrm{np}$. win, nasion, liści tytoniu, owoców, zwierząt, minerałów, wód mineralnych, piwa, kwiatów, mąki (art. 1. ust. 3). Istotne jest tutaj szerokie, przełamujące pewien tradycjonalizm rozumienia pojęcia „własność przemysłowa”, zwłaszcza że obejmuje również produkty pochodzenia rolniczego, uważane zwykle za nieprzemysłowe. Tak M. Korzycka-Iwanow, Wyłączne prawo do nowej odmiany rośliny uprawnej, Warszawa 1990, s. 24 i n.; A. Patrycka-Skrzypek, Ochrona odmian roślin w świetle nowych regulacji prawnych, ZNUJ PiPWI 2005, z. 89, s. 162 i n. Union pour la Protection des Obtentiones Végétales, podpisanej w Paryżu w 1961 r. (zrewidowana w 1972, 1978 i 1991 r.). Rzeczpospolita Polska jest członkiem Związku od 1989 r. 
Obecnie obowiązująca ustawa z 30 czerwca 2000 r. Prawo własności przemysłowej ${ }^{10}$ ma w swoim tytule termin ,prawo własności przemysłowej”; jest to użycie pojęcia ,własność przemysłowa” w znaczeniu przedmiotowym i odnosi się do całości regulacji w ustawie. Z tytułem koresponduje art. 2, w myśl którego ustawa normuje stosunki w zakresie wynalazków, wzorów użytkowych, wzorów przemysłowych, znaków towarowych, oznaczeń geograficznych i topografii układów scalonych, zasad przyjmowania projektów racjonalizatorskich i wynagradzania ich twórców. Takie ujęcie własności przemysłowej częściowo odbiega od jej tradycyjnego rozumienia jako zespołu przepisów regulujących treść i ochronę praw podmiotowych, których przedmiotem są dobra niematerialne. Poza zakresem regulacji ustawy znalazł się m.in. omawiany w tym opracowaniu obszar wyłącznego prawa do odmiany rośliny.

Warto w tym miejscu przypomnieć przełomowy, również dla terminologii tego prawa, przykład z historii prawa. We Francji udzielenie patentu jako instrumentu polityki merkantylistycznej rozpoczęło się na początku XVI wieku. Jeszcze przed Rewolucją opinia publiczna zwróciła się w kierunku odrzucenia patentu, nazywanego monopolem, jako będącego w sprzeczności z wolnością handlu. Dla podkreślenia zerwania z przeszłością, który to okres zapoczątkowała Rewolucja, prawo patentowe z 1791 r. stanowiło, iż wynalazcy przysługuje naturalne prawo własności w stosunku do wynalazku. Termin ,monopol”, źle się kojarzący, zastąpiono terminem ,własność”, rozpoznawanym aprobująco. Konstrukcja własności została wprowadzona do prawa patentowego za sprawą teorii S. de Boufflera, który zaproponował, by interpretować patent jako element prawa własności, a nie jako monopol udzielany przez państwo ${ }^{11}$, jakkolwiek patenty udzielane były przez monarchę lub inną władzę publiczną. De Bouffler wiedział, że nie było w owym czasie nadziei na zachowanie instytucji przywileju patentowego, chyba że stworzy się teorię, która będzie zaakceptowana, i tak właśnie się stało.

Jednakże prawo francuskie wymagało, by ten, który otrzymał patent, miał obowiązek swoje prawo wykonywać, co więcej, wprowadzono tzw. patenty z importu, co oznaczało, że importer zagranicznych innowacji również mógł ubiegać się o udzielenie patentu. Zatem nie ,projekcja osobowości”, „,naturalne prawo do wynalazku", ale interes ekonomiczny, przemysłowa siła państwa - odgrywały tutaj zasadniczą rolę.

Jednakże konstrukcja prawa własności nadal pozostaje prototypem prawa podmiotowego dla praw własności intelektualnej jako prawo skuteczne erga omnes oraz zapewniające wyłączność korzystania i rozporządzania określonymi dobrami na rzecz określonego podmiotu. 
Trudności analizy prawnej własności intelektualnej związane są też z brakiem jasnej konstrukcji własności intelektualnej w prawie cywilnym. Jako prawo na dobrach niematerialnych zakorzeniona jest w prawie cywilnym, ale regulowana jest również przez prawo administracyjne, przede wszystkim ze względu na udzielanie patentu przez upoważniony przez państwo urząd. Kodeks cywilny nie precyzuje nawet ogólnego, modelowego jej ujęcia. ${ }^{12}$

W Unii Europejskiej, na podstawie Traktatu Wspólnot Europejskich, funkcjonują trzy pojęcia: „własność intelektualna, przemysłowa i handlowa”. W Porozumieniu Trade Aspects of Intellectual Property Rights (TRIPS) ${ }^{13}$ również występuje pojęcie „własności intelektualnej”.

Zakaz patentowania wynalazków dotyczących odmian roślin i ras zwierząt oraz czysto biologicznych sposobów hodowli roślin i zwierząt ma swoje źródło w zakorzenionej w tradycji prawnej znacznej liczby państw niechęci wobec wynalazków dotyczących żywej materii. Do połowy XX w. rośliny i zwierzęta pozostawały w zasadzie poza zakresem prawa patentowego. Rozwiązań, których przedmiotem byłyby organizmy żywe, nie uznawano za nadające się do opatentowania, chociaż w różny sposób to uzasadniano. Europejskie organy patentowe odmawiały takim rozwiązaniom technicznego charakteru, a w USA zakaz uzasadniano tym, że stanowią one produkty natury, a nie człowieka. Ponadto wynalazki takie nie spełniały wymagania powtarzalności i dostatecznego ujawnienia, ograniczone były zatem obowiązującymi przesłankami patentowalności. Chociaż ustawy patentowe nie zawierały wyraźnego zakazu patentowania wynalazków dotyczących roślin, jednakże udzielane były wyjątkowo. Kształtowanie się odrębnych systemów prawnej ochrony roślin, których początki przypadają na lata trzydzieste XX w., zgodne było zarówno z oczekiwaniami tych, których uważali, że rośliny nie spełniają wymagań niezbędnych dla objęcia ich ochrona patentową, jak i zwolenników poglądu, iż to jedynie niewłaściwa interpretacja prawa patentowego uniemożliwia patentowanie roślin $^{14}$. Pierwsza regulacja tej materii miała miejsce w USA w 1930 r. (Plant Patent Act) dla roślin rozmnażanych wegetatywnie, a dopiero w 1970 r. wydano ustawę obejmującą ochronę odmian roślin rozmnażanych generatywnie (Plant Variety Protection Act). W Europie pierwsze ustawy dotyczące szczególnej ochrony odmian roślin wydano w Holandii (1942 r.) i w Niemczech (1953 r.). Odmiany roślin znajdowały ochronę zarówno w ramach odrębnych porozumień międzynarodowych, jak też w ustawodawstwie krajowym, wzorowanym w dużym stopniu na ukształtowa-

Zob. A.Stelmachowski, Przemiany polityczne 1989 r. a model prawa własności, (w:) Przekształcenia własnościowe w Polsce (Determinanty prawne), red. S. Prutis, Białystok 1996, s. 24.

Agreement on Trade Related Aspects of Intellectual Property Rights including Trade in Counterfeit Goods (TRIPS), podpisany w Marakeszu 15 IV 1994; po raz pierwszy uregulowano w ramach GATT (WTO) handel w zakresie własności intelektualnej. TRIPS wszedł do zakresu acquis communautaire. Zob. H. Żakowska-Henzler, Wynalazek biotechnologiczny - przedmiot patentu, Warszawa 2006, s. 208 i n. i powołana tamże literatura i orzecznictwo. 
nych instytucjach prawa patentowego. Przykładowo, ówczesne prawo węgierskie w ustawie o patentowej ochronie wynalazków z 1969 r . w dodanej w 1983 r. części dotyczącej odmian roślin i zwierząt wprowadziło ochronę patentową dla hodowcy odmiany rośliny..$^{15}$ Podobnie we Włoszech, gdzie od dłuższego czasu trwał proces wyjaśniania wielu wątpliwości interpretacyjnych w drodze orzecznictwa sądowego, i w ten sposób uporano się z wieloma zastrzeżeniami wysuwanymi przez przeciwników patentowania odmian roślin. ${ }^{16}$

Model radziecki w tym zakresie, narzucony w okresie powojennym większości państw satelickich, polegał na nacjonalizacji wynalazku biologicznego, jakim jest odmiana rośliny. Uzasadnienie takiego podejścia sprowadzało się do uznania, że konstrukcja prawa własności na rzecz państwa umożliwia zarówno państwu, jak i innym jednostkom gospodarki uspołecznionej korzystanie z nowych odmian z pełną swobodą, bez opłat. Brak możliwości udzielenia prawa wyłącznego na rzecz poszczególnych podmiotów miałoby wynikać z zabezpieczenia dobra ogólnego poprzez swobodne korzystanie przez państwo z przedmiotu ochrony w interesie społeczeństwa socjalistycznego. Pomimo że z reguły odmiany były wyhodowane w jednostkach gospodarki uspołecznionej, przyznanie państwu prawa do odmian zatarło bardzo istotną różnicę, a mianowicie między uprawnieniami państwa jako właściciela o charakterze administracyjnym (imperium) a istotą uprawnień samodzielnych przedsiębiorstw państwowych, posiadających osobowość prawną względem powierzonego im mienia. ${ }^{17}$

W 1961 r. została podpisana w Paryżu konwencja międzynarodowa o ochronie nowych odmian roślin, zwana dalej Konwencją UPOV, która wprowadziła system ochrony odmian roślin sui generis. System ten stał się modelem dla bardzo dużej liczby państw nie tylko europejskich, ale również państw obu kontynentów amerykańskich, Azji i Australii.

Stosownie do Konwencji UPOV wyłączne prawo (ang. breeder's right) odnosi się do materiału siewnego odmiany, materiału ze zbioru odmiany, produktów wytworzonych bezpośrednio z materiału ze zbioru, odmian pochodnych i innych określonych odmian. Wyłączne prawo może być rozszerzone na inne działania wskazane przez państwo będące członkiem UPOV, które nie są określone w Konwencji UPOV (art. 14 Konwencji UPOV).

Zasadniczą treścią tego prawa jest szeroko pojęty obrót materiałem siewnym odmiany. Hodowca ma decydujący wpływ na obrót materiałem rozmnożeniowym odmiany i od niego zależy, w jakich warunkach i jakimi metodami będzie przepro-

15 Zob. M. Korzycka-lwanow, Wyłączne prawo..., s. 25 i 49 i n.

16 Dekret nr 974 z 12 sierpnia 1975 r. zm. Dekretem nr 338 z 22 czerwca 1979 r. i ustawą nr 620 z 14 października 1985 r. Zob. M. Korzycka-Iwanow, Wyłączne prawo..., s. 25.

17 Na ten temat szerzej w M. Korzycka-Iwanow, Wyłączne prawo..., s. 46 i n. 
wadzał rozmnażanie roślin. Może też określać warunki przechowywania, transportu i sprzedaży materiału siewnego.

Po wejściu w życie Konwencji UPOV państwa-sygnatariusze Konwencji wprowadzały w swoich ustawodawstwach regulacje zgodne z modelem UPOV, który wykluczał istnienie na terytorium jednego państwa dwóch równoległych systemów prawnej ochrony odmian roślin. W prawie polskim po raz pierwszy uregulowano prawo wyłączne hodowców odmian roślin w ustawie z 1987 r. o nasiennictwie. W dwa lata później, w 1989 r. Polska przystąpiła do Konwencji UPOV i stała się członkiem Związku UPOV. W 1995 r. wydana została nowa ustawa o nasiennictwie, w której poczyniono w zakresie prawa wyłącznego zmiany dostosowujące przepisy krajowe zarówno do kolejnej rewizji Konwencji UPOV (z 1991 r ), jak też do prawa wspólnotowego.

Kolejne zmiany przepisów w zakresie prawa wyłącznego związane były z ciągłymi pracami legislacyjnymi nad zbliżaniem prawa krajowego do prawa wspólnotowego, w szczególności do treści rozporządzenia 2001/94/EC w sprawie wspólnotowego prawa do odmian roślin. Od 1 maja 2004 r. obowiązują ustawy: z 26 czerwca 2003 r. o nasiennictwie ${ }^{18}$ oraz ustawa z 26 czerwca 2003 r. o ochronie prawnej odmian roślin ${ }^{19}$. Dokonano rozdzielenia w osobnych ustawach materii dotyczącej nasiennictwa oraz ochrony prawnej odmian roślin. Jak już wspomniano, do czasu wejścia w życie obu tych ustaw, czyli do dnia uzyskania przez Rzeczpospolitą Polską członkostwa w Unii Europejskiej, ochrona prawna odmian roślin regulowana była w poprzednio obowiązujących ustawach o nasiennictwie.

Sytuacja prawna uległa zasadniczej zmianie, po zmianie Konwencji UPOV w 1991 r., ze względu na uchylenie zakazu podwójnej ochrony, tj. za pomocą wyłącznego prawa i patentu. $Z$ chwilą wejścia w życie tej zmiany strony związane nowym tekstem mają możliwość wprowadzić, jako alternatywny, system ochrony patentowej odmian roślin.

Przesłanki uzyskania wyłącznego prawa zawarte w Konwencji UPOV i w systemach prawnych państw-sygnatariuszy Konwencji są mniej restrykcyjne niż w przypadku patentu, jednak i zakres ochrony jest węższy. Jako prawo pokrewne patentowi, wyłączne prawo do odmiany rośliny charakteryzują określone podobieństwa do prawa wynalazczego, co uzasadnia sięganie do analogii z tym obszarem prawa.

Zakaz patentowania odmian roślin i ras zwierząt zawiera Konwencja o patencie europejskim, jak również rozporządzenie Rady 2100/94 w sprawie wspólnotowe-

Dz.U. Nr 137 poz. 1299. Ustawa o nasiennictwie reguluje sprawy rejestracji odmian roślin uprawnych dla celów obrotu oraz wytwarzania, oceny oraz obrotu i kontroli materiałem siewnym odmian. Ponadto ustawa uwzględnia wspólny katalog odmian dopuszczonych do obrotu i wspólne wymagania dotyczące materiału siewnego i szkółkarskiego. 
go prawa do odmian roślin oraz Dyrektywa 98/44/WE o ochronie prawnej wynalazków biotechnologicznych ${ }^{20}$. Polska ustawa z 30 czerwca 2000 r.: Prawo własności przemysłowej stanowi, iż ,patentów nie udziela się /.../ na odmiany roślin /.../" (art. 2921).

Natomiast w prawie międzynarodowym, zgodnie z art. 27 ust. 3b Porozumienia TRIPS, ustanowiono standard ochrony odmian roślin w sposób następujący. Nie jest możliwe pozostawienie nowych odmian poza jakimkolwiek systemem ochrony własności intelektualnej. Może to być patent, forma sui generis (tu zasadniczo model Konwencji UPOV) lub kombinacja obu tych systemów. W TRIPS sytuacja prawna wszelkich praw wyłącznych (w tym również patentu i form sui generis) w zakresie handlu materiałem siewnym odmian chronionych jest tożsama.

W ramach własności intelektualnej nastąpił też wyraźny rozziew pomiędzy twórcą nowości a tym, który nowość tę będzie eksploatował. Nowoczesne technologie rozwijają się bowiem na skutek pracy całych zespołów. Samozatrudniający się niegdyś inwestor jest dziś tym, kogo zatrudnia wielki przemysł, a więc pracownikiem firmy. W szczególności wielkie międzynarodowe koncerny (multinationals) stały się ośrodkami popierania wynalazczości, a ich działalność nie zawsze idzie w parze z interesem publicznym. Własność intelektualna stała się swego rodzaju informacją o handlowej wartości, jest zarazem odbiciem określonej twórczości, której państwo udziela wyłączności zarobkowego korzystania na długi już z reguły okres czasu, prowadzącej do pozycji monopolisty ${ }^{22}$. Wydłużający się ciągle czas trwania praw wyłącznych wyraźnie taką tendencję potwierdza, gdy chodzi o nowe odmiany roślin ustalony początkowo na 15 i 17 lat, obecnie osiągnął długość 25 i 30 lat (dłuższe okresy dotyczą odmian winorośli, drzew i ich podkładek).

Treść własności intelektualnej w rolnictwie w ramach bądź specyficznej dla odmian roślin konstrukcji (nazywanej też w literaturze prawem wyłącznym sui generis) bądź w zakresie patentu, kształtuje się zatem wyraźnie pod wpływem czynników ekonomicznych, określających pozycję podmiotów tej własności (firm hodowlanych, biotechnologicznych). Powstaje zatem uzależnienie rozwoju zakresu praw wyłącznych do materiału biologicznego od gry sił rynkowych.

Ze względu na duże zyski, jakie przynosi przemysł biotechnologiczny, można twierdzić, że własność intelektualna przekształca się w handlową własność intelektualną, ponieważ głównym celem związanym z uzyskaniem tego prawa jest w isto-

Zob. H. Żakowska-Henzler, w rozdz. V 1.C Wpływ Dyrektywy na treść zakazu patentowania odmian roślin w prawie europejskim, (w:) Wynalazek biotechnologiczny, przedmiot patentu, Warszawa 2006, s. 218 i n.

21 Stosownie do art. 29 patentów nie udziela się na: odmiany roślin lub rasy zwierząt oraz czysto biologiczne sposoby hodowli roślin lub zwierząt; przepis ten nie ma zastosowania do mikrobiologicznych sposobów hodowli ani do wytworów uzyskiwanych takimi sposobami.

$\mathrm{Na}$ temat skrajnej postaci monopolu, tzw. species patents, które przekroczyły akceptowalne granice patentowania wynalazku zob. People, Plants, and Patents, praca zbiorowa, International Development Research Center, Ottawa 1994, s. 9 i n. 
cie sprzedaż i osiąganie zysków. Zyski związane z nowościami technologicznymi, $\mathrm{np}$. w zakresie upraw roślin zawierających organizmy modyfikowane genetycznie, mają tu swój poważny udział²3.

Możliwość wyłączenia ze zdolności patentowej, zgodnie z Konwencją o patencie europejskim, TRIPS, Dyrektywą 98/44/WE o ochronie prawnej wynalazków biotechnologicznych i krajowym prawem własności przemysłowej - odmian roślin, ras czy gatunków zwierząt oraz ściśle biologicznych sposobów produkcji, nie oznacza, że wyłączenie to dotyczy roślin i zwierząt jako takich. Ochrona patentowa produktu może być zatem udzielana na wynalazki dotyczące roślin i zwierząt. Zgodnie $\mathrm{z}$ art. 4 ust. 2 Dyrektywy 98/44/WE wynalazki, które dotyczą roślin i zwierząt, mają zdolność patentową, jeżeli możliwość technicznego wykonania wynalazku nie ogranicza się do szczególnej odmiany rośliny lub rasy zwierząt. Wyjaśniono również (w pkt 31 preambuły), że odmiana rośliny definiowana jest przez cały genom i dlatego genom jako całość stanowi o jej indywidualności i odmienności od innych odmian. Natomiast grupa roślin wyróżniona na podstawie jednego tylko konkretnego genu, a nie całego genomu, nie stanowi odmiany, a zatem nie jest objęta ochroną przysługującą nowym odmianom roślin i dlatego też nie odnosi się do niej zakaz patentowania, nawet jeśli w ramach tej grupy są nowe odmiany roślin.

Istotne również, iż Porozumienie TRIPS zezwala na wyłączenie z patentowania roślin i zwierząt oraz biologicznych sposobów ich produkcji (art. 27.3.b). Inne sposoby, a mianowicie niebiologiczne, jak też mikrobiologiczne, nie są tu ujęte; zezwala się zatem na patent na roślinę lub zwierzę otrzymane sposobami mikrobiologicznymi ${ }^{24}$.

Przepis ten ma swoje konsekwencje, skoro bowiem możliwość wyłączenia patentowania nie dotyczy mikroorganizmów oraz mikrobiologicznych systemów, jest jednocześnie sugestią, że państwa członkowskie powinny przewidzieć ochronę , i to właśnie patentową, dla wynalazków z dziedziny biotechnologii. Zasada ta została również wprowadzona do Dyrektywy 98/44 Parlamentu Europejskiego i Rady UE o ochronie prawnej wynalazków biotechnologicznych.

Należy zatem stwierdzić, że obejmowanie nowości w obrębie flory rolniczej, które coraz częściej dotyczą grup roślin i odmian transgenicznych, konstrukcją własności intelektualnej zarówno w regulacjach dotyczących samej treści tej konstrukcji (patenty, prawa wyłączne sui generis), jak i w regulacjach dotyczących handlu tą własnością, jest swego rodzaju „zezwoleniem” ustawodawcy na wzmacnianie pozycji uprawnionego z tytułu własności intelektualnej. W praktyce oznacza to dyk- 
tat firm (skoncentrowanego kapitału) na określony kierunek badań przynoszących zysk, a co za tym idzie - wprowadzanie do obrotu nowych technologii (np. w postaci roślin transgenicznych), co z kolei związane jest ze zwiększaniem ryzyka, tak gdy chodzi o ekosystem, jak i zdrowie człowieka.

Trzeba zaznaczyć, że cele doświadczalne w dziedzinie wynalazczości są uniwersalną formułą, wykluczającą naruszenie patentu. Nie narusza się patentu przez stosowanie wynalazku dla celów badawczych i doświadczalnych, dla dokonania jego oceny, analizy albo nauczania (art. 69 pkt 3 Prawa własności przemysłowej).

Gdy chodzi o odmiany roślin, jako cele doświadczalne należy rozumieć wszelkiego rodzaju badania, w tym zmierzające do oceny wartości gospodarczej odmiany w danym kraju. Badania te nie mogą jednak prowadzić do uzyskiwania korzyści majątkowych z materiału siewnego chronionej odmiany.

Celów doświadczalnych nie należy mylić z posłużeniem się odmianą dla tworzenia nowych odmian, czyli z hodowlą twórczą. Korzystanie z odmian roślin dla celów hodowli twórczej objęte jest, zgodnie z Konwencją UPOV i prawem wspólnotowym ochrony odmian roślin, tzw. przywilejem hodowcy - research exemption. W zasadzie wszystkie metody stosowane w hodowli roślin wymagają użycia istniejących odmian. Odmiennie niż przy wynalazkach, kolejny hodowca będzie zawsze korzystał, jako ze źródła zmienności z innych odmian, wśród których mogą być również odmiany chronione. Prawo hodowcy wygasa tylko w stosunku do handlowego obrotu konkretnym, aktualnie istniejącym materiałem rozmnożeniowym wprowadzonym na rynek. Przywilej hodowcy polega zatem na możliwości swobodnego używania również odmian chronionych, bez obowiązku uzyskania zgody hodowcy tej odmiany. Przywilej hodowcy, który jest charakterystyczny dla systemu ochrony UPOV, jednocześnie odróżnia prawo wyłączne od patentu.

W preambule do rozporządzenia wspólnotowego 2100/94 stwierdza się, że odmiany roślin stwarzają szczególny problem, gdy chodzi o możliwość stosowania konstrukcji własności przemysłowej i, co istotne, zezwala na krajową regulację ochrony (art. 3). Ustawodawstwo w tym zakresie rozwija się zatem w ramach ustawodawstwa krajowego państw członkowskich. W tej sytuacji, czytamy w preambule do rozporządzenia, wydaje się właściwe stworzenie regulacji wspólnotowej, która, współistniejąc z systemami krajowymi, pozwala na udzielenie prawa wspólnotowego skutecznego na terytorium Wspólnoty. System zawarty w rozporządzeniu 2001/94/EC jest zgodny z modelem Konwencji UPOV i jako system sui generis (sole and exclusive form of Community industrial property rights for plant varietes) wyklucza możliwość patentowania odmian roślin. Relacje prawa wspólnotowego i krajowego zostały ustalone w ten sposób, że każda odmiana, która jest przedmiotem ochrony wspólnotowego prawa do odmiany, nie może być przedmiotem ochrony krajowego prawa do odmiany (national plant variety right) lub patentu do 
odmiany. Każde z tych praw (a zatem wyłączne prawo hodowcy lub patent) przyznane niezgodnie z tą zasadą jest nieskuteczne (shall be ineffective). Jeżeli hodowca uzyskał prawo do odmiany w porządku prawa krajowego przed udzieleniem prawa wspólnotowego do tej samej odmiany, nie może korzystać z ochrony prawa do odmiany uzyskanego w prawie krajowym tak długo, jak długo jest skuteczne wspólnotowe prawo do odmiany (art. 92 rozporządzenia 2100/94/WE).

Polska ustawa stanowi, że wyłącznego prawa nie przyznaje się, jeżeli odmiana została zgłoszona do ochrony albo jest chroniona przez Wspólnotowy Urząd Ochrony Odmian Roślin (CPVO). Jeżeli hodowca odmiany chronionej wyłącznym prawem w Rzeczypospolitej Polskiej uzyska wspólnotowe wyłączne prawo do tej odmiany, to w okresie wykonywania tego prawa nie może wykonywać wyłącznego prawa uzyskanego w Rzeczypospolitej Polskiej (art. 27 ust. 2).

$$
* * *
$$

Konkludując należy stwierdzić, że wyłączne prawo do odmiany potraktowane zostało w doktrynie jako prawo pokrewne prawom $\mathrm{z}$ własności przemysłowej; w szczególności korelacje z prawem wynalazczym są wyraźne. Na obszarze Europy obowiązuje co prawda wyraźny zakaz patentowania odmian roślin, ale w prawie poszczególnych państw na innych kontynentach patentowanie odmian jest dopuszczalne. Standard międzynarodowy zawarty w Porozumieniu TRIPS również takiego zakazu nie wprowadza.

Wydaje się, że decydującym czynnikiem mającym znaczenie dla dalszego rozwoju tych unormowań jest zakres uprawnień hodowcy oraz użytkownika odmiany (posiadacza gruntu). Dokonująca się od wielu lat w regulacjach tego obszaru „ekspansja" prawa hodowcy umacnia jego pozycję w stosunku do użytkownika odmiany rośliny. Niewykluczone, że model UPOV jeszcze długo będzie obowiązywał, niemniej wprowadzane modyfikacje w pierwszym rzędzie do Konwencji UPOV i w ślad za Konwencją do prawa wspólnotowego i krajowego państw-sygnatariuszy Konwencji, w wielu aspektach, głównie o charakterze handlowym, będą skutkować w przyszłości coraz większym zbliżeniem wyłącznego prawa do odmiany - do konstrukcji patentu.

\section{Exclusive right to variety (breeder's right) within the field of intellectual property}




\section{Summary}

The concept of intellectual property in the legal systems of individual states is constantly expanded, also because of accession to international conventions, treaties and agreements. Primarily however, the subject scope increases steadily as a growing number of so-called intellectual subjects achieve the status of non-material property, to which exclusive rights apply.

The exclusive right to a plant variety, regulated by the Law of June 26, 2003 on the legal protection of plant varieties, on grounds of a model laid down in the International UPOV Convention, is regarded an industrial property law. The breeder's right should thus be considered a neighbouring right or one related to the rights gathered under the collective title of industrial property.

The WTO/TRIPS Agreement creates an international standard of protection for plant varieties, obligating states to protect plant varieties by patents, sui generis rights or a combination of the two.

The prohibition of patenting plant and animal varieties within the European Patent Convention, directive 98/44/EC on the legal protection of biotechnological inventions and domestic legislation on protection of industrial property - do not mean that the exclusion refers to plants and animals per se. Exclusion from patenting does not concern microbiological cultivation nor the effects of this which allows patent protection of inventions from the sphere of biotechnology (biotechnological inventions).

It appears that the decisive factor, significant for the further development of exclusive rights to variety, is the extent of protection awarded to its cultivator, which at the same time will condition the legal situation of the variety's user (land possessor). 